\title{
KONTRIBUSI PONDOK PESANTREN HIDAYATULLAH BAGI MASYARAKAT PALANGKA RAYA
}

\author{
Hikmah $^{1}$, Zainap Hartati ${ }^{2}$ \\ ${ }^{1}$ Pascasarjana IAIN Palangka Raya, Kalimantan Tengah \\ Email: hikmahpky76@gmail.com
}

\begin{abstract}
Pondok Pesantren is a unique Islamic religious education institution. Pesantren as the oldest Islamic education system in Indonesia, socio-religious institutions, and educational vehicles for Muslims who want to explore religious knowledge. Pesantren is a center for the study and exploration of the treasures of Islamic knowledge and the center of the da' wah movement to spread Islam in Indonesia. The purpose of Islamic boarding school education is to form a character who is faithful and devoted to Allah SWT, has noble character, is useful for society, is able to be independent, loves science in developing a personality with good character. This study uses a qualitative descriptive method, namely collecting data and drawing conclusions. The Hidayatullah Islamic Boarding School was founded by Ustadz Anwar Timumun at the end of 1995, he pioneered da'wah in Bumi Tambun Bungai, Palangkaraya City. The concept of Hidayatullah Islamic boarding school education is based on monotheism, with education levels from PAUD, elementary and junior high schools creating a generation of intelligent, pious and monotheistic. The contribution of the Hidayatullah Islamic boarding school to the people of Palangka Raya City is in the field of education such as formal and informal education, in the religious field, among others, establishing the Tahfizh Hidayatullah House and the Taklim Council, in the social field, among others, establishing orphanages and cooperatives, and spearheading large religious events.
\end{abstract}

Keywords : Contributions, Hidayatullah Islamic Boarding School, Society

\begin{abstract}
Abstrak
Pondok Pesantren merupakan lembaga pendidikan keagamaan Islam yang unik. Pesantren sebagai sistem pendidikan Islam tertua di Indonesia, lembaga sosial keagamaan, dan wahana pendidikan bagi umat Islam yang ingin mendalami ilmu agama. Pesantren merupakan pusat kajian dan eksplorasi khazanah ilmu keislaman dan pusat gerakan dakwah untuk menyebarkan agama Islam di Indonesia. Tujuan pendidikan pesantren adalah membentuk karakter yang beriman dan bertakwa kepada Allah SWT, berakhlak mulia, berguna bagi masyarakat, mampu mandiri, mencintai ilmu dalam mengembangkan kepribadian berakhlakul karimah. Penelitian ini menggunakan metode deskriptif kualitatif, yakni mengumpulkan data serta ditarik kesimpulan. Pondok Pesantren Hidayatullah didirikan Ustadz Anwar Timumun akhir tahun 1995, beliau merintis dakwah di Bumi Tambun Bungai Kota Palangkaraya. Konsep Pendidikan Pesantren Hidayatullah berbasis Tauhid, dengan jenjang Pendidikan dari PAUD, SD dan SMP mencetak generasi cerdas, sholeh dan bertauhid. Kontribusi pondok pesantren Hidayatullah bagi masyarakat Kota Palangka Raya yaitu dalam bidang pendidikan seperti pendidikan formal dan informal, dalam bidang keagamaan antara lain mendirikan rumah Tahfizh Hidayatullah dan Majelis Taklim, Dalam bidang sosial kemasyarakatan antara lain mendirikan panti asuhan dan koperasi, serta mempelopori acara besar keagamaan.
\end{abstract}

Kata kunci : Kontribusi, Pondok Pesantren Hidayatullah, Masyarakat 


\section{Pendahuluan}

Pondok Pesantren adalah sebuah lembaga pendidikan Islam di Indonesia. Pesantren merupakan jenis lembaga Pendidikan Islam tertua dan telah mengakar kuat dalam sosial budaya bangsa Indonesia sejak lama. Pesantren merupakan pusat kajian dan eksplorasi khazanah ilmu keislaman dan pusat gerakan dakwah untuk menyebarkan agama Islam di masyarakat. Pesantren juga dikenal sebagai pembela Islam ortodoks. Pondok Pesantren adalah lembaga pendidikan agama di Indonesia, bukan hanya karena keberadaannya yang lama, tetapi juga karena budaya, metode dan jaringan yang dianut oleh lembaga-lembaga keagamaan.

Keberadaan pondok pesantren tidak lepas dari pembaharuan dan perubahan yang berdasarkan keseimbangan, dengan tetap melestarikan tradisi dan secara positif merangkul hal-hal baru. Reaksi Pesantren berbeda-beda terhadap perubahan zaman dan dinamika. Secara keseluruhan perubahan pesantren perlahan dan sulit diamati. Kyai memegang peranan penting dalam proses pembaharuan kehidupan sebuah pesantren. Secara keseluruhan, Kyai sangat berpikiran terbuka untuk mempromosikan modernisasi pesantren dalam konteks perubahan sosial, tanpa mengabaikan aspek positif dari sistem pendidikan Islam tradisional.

Pesantren adalah bagian dari pendidikan Islam Indonesia dan didirikan untuk memenuhi kebutuhan dan tuntutan zaman. Dapat dilihat melalui sejarah, sebenarnya Pesantren lahir dari pengakuan dan tugas dakwah Islam, dan dengan menciptakan calon para Da'i dan Ulama, pesantren sudah menjadi harapan dari masyarakat Indonesia (Yunus, 2015).

Pemerintah telah memberikan dukungan dan arahan untuk menjaga Pesantren dapat berkembang dalam melayani kebutuhan-kebutuhan masyarakat, dan untuk menjaga pesantren agar tetap berkembang. Orientasi pengembangan pesantren pertama ditekankan, memperkuat tujuan kelembagaan pesantren dalam kerangka pendidikan nasional dan meningkatkan potensinya sebagai lembaga sosial. Kedua, menyempurnakan kurikulum secara pedagogis untuk meningkatkan efektivitas dan efisiensi pengembangan pesantren. Ketiga, menggalakkan pendidikan keterampilan di pesantren untuk mengembangkan potensi pesantren dari segi infrastruktur sosial dan taraf hidup masyarakat. Dan keempat, keputusan bersama tiga menteri (SKB 3 Menteri tahun 1975) tentang peningkatan mutu pendidikan di Madrasah melengkapi bentuk Pesantren dengan Madrasah (Zulhimma, 2013).

Salah satu keunggulan podok pesantren adalah setiap pesantren memiliki keunikannya masing-masing. Peran tradisi di masyarakat sekitar menjadikan Pesantren sebagai lembaga penelitian yang penting. Keunikan ini ditandai dengan banyaknya variasi antara satu pesantren dengan pesantren lainnya, namun dalam beberapa hal terdapat kesamaan yang umum.

Berdasarkan data Kemenag Kalteng tahun 2020, dari data yang terhimpun terdapat 10 Pondok Pesantren khususnya di Kota Palangkaraya. Salah satunya adalah pondok pesantren Hidayatulah Palangka Raya yang beralamat di jalan Danau Rangas no. 6 Kecamatan Jekan Raya. Pesantren Hidayatullah merupakan salah satu pesantren yang berkembang pesat. Salah satu ciri khas Pondok Pesantren Hidayatullah adalah belajar membaca, menghafal, memahami dan 
mengamalkan Al-Qur'an, selain penekanan khusus pada pembelajaran AlQur'an. Selain itu, Pondok Pesantren Hidayatullah tidak meninggalkan kajiankajian kontemporer seperti kitab-kitab Islam klasik, kebudayaan Islam serta kajian bahasa Arab, bahasa Inggris, dan ilmu komputer.

Kehadiran pondok pesantren Hidayatullah Palangkaraya menjadi hal baru bagi penduduk Palangkaraya. Penerimaan pondok pesantren di masyarakat mempengaruhi kehidupan masyarakat. Sebagian masyarakat pasti akan ada yang mendukung, namun juga pasti ada masyarakat yang tidak mendukung terhadap suatu pondok pesantren, dan dampak dari sebuah pondok pesantren tersebut tentu akan langsung dapat dirasakan. Berdasarkan hal tersebut, penulis ingin menggali informasi tentang bagaimana sejarah perkembangan pondok Pesantren Hidayatullah Palangka Raya, serta apa saja kontribusinya bagi masyarakat sekitar.

\section{Metode}

Penelitian ini menggunakan metode dengan pendekatan deskriptif kualitatif. Penelitian deskriftif kualitatif adalah mengumpulkan data berdasarkan faktor-faktor yang menjadi pendukung terhadap objek penelitian, kemudian menganalisa faktor-faktor tersebut untuk dicari peranannya (Arikunto, 2010). yakni dengan cara observasi, pengumpulan data, wawancara, dan pengambilan kesimpulan. Dengan metode penelitian ini berupaya mendapatkan data kongkrit tentang pondok pesantren Hidayatullah Palangkaraya.

Dalam penelitian ini, peneliti membagi sumber sebagai berikut: (1) Sumber primer yaitu data yang diperoleh atau dikumpulkan langsung dilapangan melalui observasi dan wawancara, data tersebut meliputi : Sejarah perkembangan Ponpes Hidayatullah dan kontribusinya bagi masyarakat. (2) Dokumen sekunder yaitu data yang diperoleh dari buku, literatur, dan jurnal yang berkaitan dengan penulisan artikel. Tempat penelitian adalah Pondok Pesantren Hidayatullah Palangkaraya yang beralamat di Jl. Danau Rangas Palangkaraya.

\section{Hasil dan Pembahasan \\ Hakikat Pesantren}

Pesantren sering dimaknai sebagai asrama santri atau asrama untuk belajar mengaji (KBBI, 2000). Dalam komunitas Pesantren memiliki santri, ada kiai, ada tradisi pengajian serta tradisi lainnya, dan beberapa bangunan pesantren digunakan oleh santri untuk melakukan segala aktivitasnya selama sehari penuh. Kata pesantren berasal dari kata santri dengan awalan "pe" dan akhiran "an", dan pengucapan kata tersebut berubah menjadi nama fisik bangunan "en" (pesantren). Asrama tempat tinggal siswa. Kata santri sendiri berasal dari kata cantric. Ini berarti murid dari rishi, tinggal di tempat yang disebut Padepokan. Pesantren ditinjau dari beberapa aspek: keberadaan murid (Cantric dan santri), keberadaan guru (kyai dan resi), keberadaan gedung (Pesantren dan padepokan), dan terakhir adanya keberadaan kegiatan pendidikan dan pembelajaran (Suwito, 2009). 
Di sisi lain, pesantren adalah lembaga sosiologi yang berfungsi sebagai sarana pendidikan bagi umat Islam yang ingin mendalami ilmu agama. Perguruan tinggi Islam adalah lembaga pendidikan agama Islam, namun Pesantren memiliki simbol sosial dengan sistem sosial di masyarakat. Hal ini karena pondok pesantren memiliki pendekatan sosial yang unik. Pertama, kepribadian Kyai, kedua santri, ketiga, kemandirian dan independent, keempat, jaringan sosial yang kuat di kalangan alumnus pesantren (Mun'im, 2009).

Pesantren merupakan sistem pendidikan Islam tertua, dan dianggap sebagai hasil budaya Indonesia. Seiring dengan perkembangan masyarakat Indonesia, pendidikan di pondok pesantren pun ikut berkembang (Shofiyyah, 2019). Singkatnya, pondok pesantren adalah sistem pendidikan Islam tertua di Indonesia, lembaga sosial keagamaan, dan wahana pendidikan bagi umat Islam yang ingin mendalami ilmu agama.

\section{Peran dan Fungsi Pesantren}

Sebuah Lembaga dapat digolongkan sebagai pesantren jika memenuhi unsur-unsur pesantren. Unsur-unsur sistem pendidikan dipesantren dapat dikelompokkan sebagai berikut:

1. Pelaku atau praktisi; Kyai, ustadz, santri, dan pengurus.

2. Fasilitas: masjid, tempat tinggal utama, asrama imam, perguruan tinggi atau asrama, sekolah atau madrasah, olahraga, lahan pertanian atau peternakan, makam, dan lain-lain.

3. Sarana Perangkat lunak : Tujuan Kurikulum/program, kitab, penilaian, aturan, perpustakaan, pusat dokumentasi, Informasi, metode pengajaran (sorogan, bandongan dan halaqah), keterampilan, pusat pengembangan masyarakat menengah dan perangkat pendidikan lainnya (Shiddiq, 2015).

Dalam proses pembentukan kepribadian, Pondok pesantren berfungsi baik sebagai lembaga pendidikan agama dengan fungsi menyebarkan dan mengembangkan ilmu agama Islam, maupun sebagai lembaga administrasi. Kinerja pesantren memiliki kontrol yang ketat terhadap norma dan nilai, khususnya pada ibadah tertentu dan pada beberapa norma muamalah. Dapat dikatakan bahwa ada beberapa standar orientasi atau pembelajaran untuk menyelesaikan dengan bijak dan cepat. Dengan demikian, meskipun pendidikan di pondok pesantren tidak banyak menekankan pada aspek kognitif, proses pendidikan berfokus pada aspek afektif dan psikomotor (Shofiyyah, 2019).

\section{Tujuan Pendidikan Pesantren}

Sebagai lembaga pendidikan Islam, Pesantren, baik secara formal maupun dalam bentuk slogan yang ditimbulkan oleh pengaruh Pesantren, jelas menetapkan tujuan dan cita-cita yang sesuai dengan nilai-nilai Islam. Apalagi keberadaan pesantren merupakan bagian yang tidak terpisahkan dari masyarakat. Oleh karena itu, pesan-pesan yang dapat dikumpulkan dari masyarakat juga menjadi pedoman untuk mengembangkan tujuan pendidikan bagi Pesantren.

Pada suatu lokakarya yang diadakan di Jakarta pada bulan Mei 1987 untuk pengembangan pendidikan pesantren, tujuan kelembagaan pendidikan pesantren ditetapkan sebagai berikut. 


\section{Tujuan Umum}

Membina warga negara agar berkepribadian muslim dengan ajaran-ajaran agama Islam dan menanamkan rasa keagamaan tersebut dalam semua segi kehidupannya serta menjadikannya sebagai orang yang berguna bagi agama, masyarakat, dan negara.

2. Tujuan khusus

a. Mendidik siswa atau santri untuk menjadi manusia muslim selaku kaderkader ulama dan mubaligh yang berjiwa ikhlas, tabah, tangguh, wiraswasta dalam mengembangkan syariat-syariat Islam secara utuh dan dinamis.

b. Mendidik siswa atau santri untuk memperoleh kepribadian dan mempertebal semangat kebangsaan agar dapat menumbuhkan manusiamanusia pembangunan bangsa dan negara.

c. Mendidik penyuluh pembangunan mikro (keluarga) dan regional (pedesaan/ masyarakat lingkungannya).

d. Mendidik siswa atau santri menjadi tenaga-tenaga yang cakap dalam berbagai sektor pembangunan khususnya dalam pembangunan mental spiritual.

e. Mendidik siswa atau santri untuk membangun meningkatkan kesejahteraan sosial masyarakat dalam rangka usaha pembangunan bangsa (Proyek Pembinaan dan Bantuan kepada Pondok Pesantren, 1985).

Manfred Ziemek tertarik pada perspektif mengintegrasikan aspek perilaku dan intelektual. Menurut Ziemak tujuan pesantren adalah "menciptakan kepribadian, memantapkan akhlak dan melengkapinya menggunakan pengetahuan. Sedangkan menurut Mastuhu tujuan pendidikan pesantren adalah "memajukan dan mewujudkan kepribadian Muslim, yaitu kepribadian yg beriman dan bertakwa pada Tuhan, berakhlak mulia, berguna bagi orang lain, yakni sebagai pelayan masyarakat sebagaimana kepribadian Nabi Muhammad (mengikuti Sunnah Nabi), sanggup berdiri sendiri, bebas dan teguh pada kepribadian, mengembangkan dan menegakkan kejayaan Islam pada tengahtengah masyarakat, dan mencintai ilmu dalam rangka mengembangkan karakter manusia (Ziemek, 1986).

Ringkasnya, tujuan pendidikan pesantren adalah membentuk karakter yang beriman dan bertakwa kepada Allah SWT, berakhlak mulia, berguna bagi masyarakat, mampu mandiri, mencintai ilmu dalam mengembangkan kepribadian berakhlakul karimah.

\section{Perkembangan Pondok Pesantren Hidayatullah Palangka Raya \\ 1. Sejarah Pondok Pesantren Hidayatullah}

Akhir Tahun 1995, Ust. Anwar Timumun, seorang kader Hidayatullah yang pernah bertugas di Samarinda, mencoba merintis dakwah baru di Bumi Tambun Bungai Kota Palangka Raya. Berbekalkan keyakinan dan semangat, beliau bersama 2 orang sahabatnya menemui saudara mereka di Jl. Nyai Undang Kota Palangka Raya. Anwar dkk menjelaskan maksud kedatangan mereka, dan pak Rumsyah Bagan langsung merespon dengan sangat baik. Mengawali dakwahnya di Palangka Raya, ia gencar silaturahim dengan masyarakat ataupun pejabat Pemerintah setempat. Berawal dari menyewa sebuah tempat tinggal pada Jl. RTA Milono menjadi wadah penampungan para santri, ternyata respon 
warga dan pemerintah sangat besar, mengingat forum dakwah semisal Pondok Pesantren atau Panti Asuhan dalam waktu itu masih sangat minim.

Seiring berjalannya waktu tepatnya di akhir Tahun 1998 ketika kampus Hidayatullah pindah dari Jl. RTA Milono ke Jl. Danau Rangas, memanfaatkan tanah wakaf yang diberikan oleh (Alm) Bapak Rochana Zulki, SH. Di saat itu pula pak Anwar Timumun diberi kepercayaan baru untuk membuka pondok Pesantren Hidayatullah di Kabupaten Kotawaringin Barat Pangkalanbun. Estafeta kepemimpinan Pondok Pesantren Hidayatullah di pegang oleh Ust. Muhammad Robi'in, sebelumnya beliau bertugas di tanah Papua. Diakhir tahun 2017 beliau wafat selanjutnya kepemimpinan dipegang oleh Ust. Muhammad Yunus Assegaf dan sekarang kepemimpinan pondok di pimpin oleh Ust. Huzaifah, S.Sos.

Uswah yayasan pondok Pesantren Hidayatullah diawali dengan penjualan majalah Hidayatullah dan Dakwah 'Asyiroh yaitu mengajar mengaji dari rumah kerumah. Dan kini, di areal tanah seluas 2 hektar telah berdiri sarana dan prasarana penunjang yayasan antara lain : Mesjid, kantor, asrama santri, gedung sekolah dan rumah pengasuh. Dengan semangat dan tekad yang kuat para pengurus pondok pesantren Hidayatullah ikut andil dalam memberikan pelayanan kepada umat, khususnya di sektor pendidikan.

Perlahan tapi pasti, pada tahun 2004, bidang pendidikan di Hidayatullah Palangka Raya khususnya TK Islam As-Sa'adah telah dibuka dan menjadi primadona. Karena dianggap berkualitas oleh masyarakat, para orang tua berlomba menyekolahkan anaknya di TK milik yayasan ini. Dan saat ini peserta didik yang sudah tercatat mencapai 90 orang disetiap tahunnya.

Pesantren sebagai sekolah Islami, seperti madrasah, dapat mewujudkan cita-cita kota Palangkaraya sebagai kota pendidikan tinggi. Lahir dari sebuah keinginan para pendahulu agar menciptakan generasi yang berkepribadian baik. Karena itu Pemerintah terus memperhatikan pendidikan, dengan dibuktikannya bantuan gedung sebagai sarana belajar bagi TK di Hidayatullah pada tahun 2004. Ini sebagai bukti perhatian dan kepercayaan masyarakat dan Pemerintah Daerah.

Pada tahun 2009 dibuka Sekolah Dasar Integral (SD IT) Hidayatullah. Pada kenyataannya, SD IT Hidayatullah merupakan SD Integral kedua yang ada di Kota Palangka Raya. Ini menjadi tantangan karena minat masyarakat untuk menyekolahkan di SD Integral Hidayatullah sangatlah besar. Disamping itu pula faktor kelulusan dari TK Hidayatullah juga turut mempengaruhi kuantitas murid. Dan setiap tahun TK Hidayatullah dapat mencetak alumnus hingga jumlah 62 anak.

SD Integral Hidayatullah membatasi atau mentargetkan jumlah siswa hanya 25 anak, namun pencapaiannya terus bertambah setelah itu. Atas bantuan dan dukungan semua pihak, SD Integral Hidayatullah dapat mencetak generasi yang Cerdas, Sholeh dan Bertauhid. Dan pada akhir tahun 2020, SD Integral Hidayatullah sudah mencapai 295 peserta didik.

Di Tahun 2018 Pesantren Hidayatullah mendirikan Sekolah Menengah Pertama (SMP) Boarding dengan program unggulan hafalan al-Qur'an. Beberapa hal yang melatar belakangi berdirinya SMP Integral Hidayatullah : Pertama, 
semakin meningkatnya lulusan dari SD Integral Hidayatullah Palangka Raya, sehingga diharapkan nantinya SMP integral Hidayatullah dapat mewadahi lulusan SD Integral Hidayatullah agar terjadi kesinambungan profil lulusannya. Kedua, melaksanakan salah satu program Yayasan Pondok Pesantren Hidayatullah dalam bidang pendidikan untuk mendirikan model sekolah Boarding (asrama), dikarenakan belum adanya model pendidikan Boarding di sekitar lingkungan pondok Pesantren Hidayatullah. Dan hingga tahun 2020 santriwan SMP Integral Hidayatullah berjumlah 28 orang.

Pesantren Hidayatullah memiliki program Diniyah Takmiliyah dimulai tahun 2008 yang berfokus di 7 (tujuh) mata pelajaran Agama Islam yaitu : Qur'an, Hadits, Aqidah, Akhlak, Fiqh, Tarikh dan Bahasa Arab. Hingga akhir tahun 2020 sudah memiliki 4 tingkatan kelas dimulai Diniyah Takmiliyah Ula 4 kelas, Diniyah Takmiliyah Wustho 2 kelas. Kemudian pada tahun berikutnya akan membuka kelas Diniyah Takmiliyah Ulya untuk santri usia 15 tahun hingga remaja. Dan terhitung bulan Desember tahun 2020 total santri Diniyah Takmiliyah Ula berjumlah 187 dan Diniyah Takmiliyah Wustho berjumlah 25 santri, Sehingga total Santriwan Santriwati Diniyah Takmiliyah 212 orang.

Visi Pondok Pesantren Hidayatullah adalah Mewujudkan Pondok Pesantren sebagai lembaga Dakwah, Pendidikan dan Sosial yang bermutu tinggi dan unggul sehingga melahirkan SDM yang siap memikul amanah Allah SWT sebagai hamba dan Khalifah-Nya. Dengan misi Menyelenggarakan Pondok Pesantren secara integral dalam aspek ruhiyah, aqliyah dan jismiyah sehingga dapat melahirkan insan kamil yang memiliki iman yang kokoh, ilmu yang luas, trampil dan berakhlaqul karimah.

Sistem Pendidikan SD IT Hidayatullah dengan menggunakan kurikulum Pendidikan 2013 dan Kurikulum Kepesantrenan (Diniyah); Menggunakan sistem Full Day School lebih terkontrol, terencana dan terarah; Kunjungan belajar dan praktikum; Pengenalan dan penerapan ITC (Information and Communication Tekhnology) sebagai persiapan menghadapi globalisasi informasi; Pembinaan akhlak dan akademik dilakukan secara seimbang dan intensif. Adapun Konsep Pendidikan SD Integral adalah Berbasis Tauhid.

Sementara Sistem Pendidikan dan Program Unggulan Kurikulum SMP Hidayatullah yaitu : Pertama, Tarbiyyah menekankan pada aspek ketauhidan atau 'aqidah (spirit Ilahiyyah), kedua, Ta'līm menekankan pada aspek akal (transfer of knowledge), ketiga, Ta' dïb menekankan pada aspek akhlak (transfer of value). Ketiganya adalah konsepsi pendidikan Islam yang digali dari sumber ajaran Islam (al-Qur'an dan al-Hadis̀) yang dalam praktiknya harus terus dikembangkan secara padu dan saling menopang antara satu dengan yang lainnya. Konsep-konsep ini harus diterapkan menurut prinsip-prinsip yang jelas dan benar.

Program Unggulan Kurikulum SMP Integral

1) Tarbiyah Ruhiyah

Pendidikan Spiritual dengan berbagai ibadah rutin dan terkontrol 24 jam. Sholat wajib berjamaah, sholat sunnah rawatib, tahajjud, dhuha, wirid, dzikir, tilawah, sholawat, dan tahfizh Al Qur'an minimal 6 Juz selama 3 tahun. 
2) Tarbiyah Tsaqofiyah

Pendidikan wawasan Iptek dan Imtaq dengan penerapan kurikulum integral berbasis tauhid. Dilengkapi berbagai muatan lokal seperti wawasan Al-Qur'an, Hadits, bahasa asing, baca kitab, serta pembelajaran ITC.

3) Tarbiyah Jasadiyah

Pendidikan olah fisik, bina bakat, bela diri, ektrakulikuler, life skill, ketangkasan dan Kepanduan atau Kepramukaan

4) Tarbiyah Qiyadiyah

Pendidikan kepemimpinan, organisasi dan Kemandirian dengan latihan mengemban berbagai amanah, tanggung jawab dan penugasan.

5) Tarbiyah Ijtima'iyah

Pendidikan sosial bermasyarakat sebagai bekal untuk pengabdian di lingkungan dan di tengah masyarakat.

Kitab - Kitab yang dipelajari di Pondok Pesantren Hidayatullah diantaranya:

1) kitab Ta'lîm al-Muta' allim Tharîq at-Ta'allum karya Imam al-Zarnûji.

2) Kitab Riyadus Sholihin karya Imam Abu Zakariya Yahya bin Syaraf AnNawawy (Imam Nawawi).

3) Kitab Al-Ajjurumiyah karya Abu Abdillah Sidi Muhammad bin Daud Ash-Shanhaji alias Ibnu Ajurrum.

4) Kitab Tafsir Ibnu Katsir karya Ismail bin Umar Al-Quraisyi bin Katsir AlBashri Ad-Dimasyqi, Imaduddin Abu Al-Fida Al-Hafizh Al Muhaddits Asy-Syafi'i.

5) Kitab Tafsir Jalalain karya oleh Jalaluddin al-Mahalli, dan kemudian dilanjutkan oleh muridnya Jalaluddin as-Suyuthi (Ponpes Hidayatullah, 2020).

\section{Kontribusi Pondok Pesantren Hidayatullah Bagi Masyarakat}

Kehadiran pondok pesantren khususnya di masyarakat perkotaan seperti Pondok Pesantren Hidayatullah yang berada tepat di Jl. Danau Rangas kelurahan Bukit Tunggal tentunya tidak berdampak kecil bagi masyarakat. Dari awal berdirinya Pondok Pesantren Hidayatullah hingga tahap perkembangan saat ini, telah terjadi berbagai pembaruan dalam waktu yang tidak singkat.

Berdasarkan observasi dan wawancara lapangan dengan pihak terkait menyangkut peran pondok pesantren Hidayatullah, didapatkan beberapa kontribusi pondok pesantren, diantaranya dalam hal pendidikan, Keagamaan dan kemasyarakatan.

\section{Bidang Pendidikan}

Pusat pendidikan Islam pondok pesantren yaitu mushola, masjid bahkan rumah kiai, mengajarkan ilmu agama kepada para santrinya. Santri biasanya duduk di lantai setengah lingkaran menghadap guru atau kyai dan membaca AlQur'an. Jam belajar biasanya diadakan pada malam hari agar tidak mengganggu pekerjaan orang tua sehari-hari. Lembaga pendidikan Islam nonformal ini merupakan cabang dari organisasi dan pembentukan pendidikan Islam pondok pesantren (Engku \& Zubaidah, 2014).

Sebagai lembaga pendidikan, Pesantren sangat memperhatikan dengan 
bidang agama (tafaqquh fi addin) dan membentuk karakter negara yang berkarakteristik. Jadi secara umum peran Pesantren sendiri adalah sebagai Lembaga pendidikan Islam, yaitu sebagai lembaga sosial dan lembaga dakwah Islam. Namun disisi lain Pesantren juga merupakan lembaga pendidikan Islam mengajarkan ajaran agama Islam dan santri memiliki pemikiran yang cerdas saling menghormati untuk saling meningkatkan akhlak (Dewi, 2020).

Dalam hal ini, pengaruh Pesantren Hidayatullah terhadap pendidikan di dalam dan sekitar pondok sangatlah besar. Pada awalnya banyak masyarakat yang tidak mengenal tentang pendidikan agama dan pada kenyataannya pendidikan agama di masyarakat masih tergolong rendah. Sejak saat itu, banyak masyarakat sekitar dan sekitarnya yang mengandalkan Kyai, Ustazh atau Ustazah untuk belajar ilmu keislaman. Kontribusi pondok Pesantren Hidayatullah terhadap masyarakat dibuktikan dengan hadirnya sekolah PAUD, SD Integral dan SMP Integral. Sekolah Dasar bertujuan untuk melatih siswa memiliki pengetahuan dasar Islam dan dapat mengamalkannya, terutama ibadah dan akhlak, untuk menciptakan generasi yang Cerdas, Sholeh dan Bertauhid.

SMP Integral mempunyai target terwujudnya santri yang memiliki kemampuan membaca al-Qur'an dengan lancar menggunakan ilmu tajwid, dengan program unggulannya hafalan al-Qur'an. Mempelajari pengetahuan dasar Islam, terutama dasar-dasar tauhid, ibadah, akhlak dan ilmu Nahwu sharf, serta belajar bahasa asing dengan baik. Oleh karena itu, hal ini memungkinkan siswa untuk menjadi individu berbakat yang fasih berbahasa Arab dan Inggris secara baik dan benar (Ponpes Hidayatullah, 2020).

Oleh karena itu, warga kota Palangkaraya dan sekitarnya mendukung penuh keberadaan pendidikan formal di Pesantren Hidayatullah. Selain itu, para santri diharapkan tidak hanya menjadi lulusan teladan, tetapi juga untuk melatih menjadi umat Islam yang beriman dan bertaqwa berdasarkan Al-Qur'an dan AlHadits.

\section{Bidang Keagamaan}

Pendirian Pesantren Hidayatullah di Palangkaraya membawa dampak besar bagi perkembangan masyarakat sekitar dalam bidang keagamaan. Peran pesantren dalam kehidupan umat adalah membimbing spiritualitas, dalam hal spiritual dan ibadah berdasarkan kegiatan tersebut. Oleh karena itu, jelas bahwa hubungan antara keduanya secara tidak langsung dapat dijadikan sebagai orientasi kegiatan Pendidikan Islam untuk menanamkan kebiasaan-kebiasaan positif pada diri siswa dan bekal dalam menghadapi masa depan hidup bermasyarakat.

Adapun kontribusi nyata Pondok Pesantren Hidayatullah dalam bidang keagamaan kepada masyarakat sekitar Pondok diantaranya sebagai berikut:

a. Rumah Tahfizh Hidayatullah; pembelajaran baca tulis Al-qur'an untuk masyarakat disekitar pondok dari anak-anak sampai orang dewasa.

b. Majelis Taklim Darul Tazkiah; Pengajian rutin keagamaan untuk masyarakat umum yang ingin memperdalam ilmu agama. 
c. Pengajian Assalam; pengajian ini dikhususkan untuk para ibu-ibu masyarakat disekitar pondok Pesantren yang ingin memperdalam agama (Ponpes Hidayatullah, 2020).

Seiring dengan perkembangannya, besar kecilnya pondok pesantren jelas terkait dengan kepercayaan masyarakat terhadap pendidikan yang diberikan oleh pondok pesantren. Hal itu menyangkut mutu, kualitas maupun kuantitas santri yang dicetak dari pondok pesantren.

Kontribusi pesantren Hidayatullah kepada masyarakat sekitar pondok dalam bidang keagamaan sangatlah penting. Banyak remaja yang dulunya dikenal sebagai preman, banyak orang lain melakukan hal-hal buruk yang tidak bermanfaat, terutama kaum muda yang lebih rentan. Mereka tidak begitu memahami ilmu agama, dan bahkan tidak banyak orang di sekitar mereka yang bisa membaca Al-Qur'an. Dengan adanya pondok ini, masyarakat secara tidak langsung diikutsertakan dalam pondok Pesantren Hidayatullah sebagai sarana untuk meningkatkan pengetahuan masyarakat dalam hal agama, khususnya dalam menghadapi tantangan dimasa modern ini.

Pesantren Hidayatullah secara teratur menyelenggarakan dakwah atau ceramah di berbagai lokasi, selain berkontribusi pada pendidikan masyarakat tentang isu-isu keagamaan. Hal ini dilakukan untuk membantu umat belajar lebih banyak tentang ajaran Islam. Pelajaran ini hanya didasarkan pada ceramah, berbeda dengan metode pengajaran yang diajarkan di mata pelajaran sekolah dengan menggunakan alat tulis dan buku, untuk memfasilitasi penyebaran Islam, sehingga penyampaiannya materinya lebih cepat.

"Kehadiran pondok Pesantren Hidayatullah membuat masyarakat sangat terbantu. Karena Pondok Pesantren dapat menjadi panutan bagi masyarakat, sehingga orang yang baru mengenal agama pada awalnya dapat mengetahui pentingnya belajar agama. Warga juga sangat terbantu dengan keberadaan Pondok Pesantren tersebut. Banyak warga sekitar yang menyekolahkan anaknya di Pesantren Hidayatullah ini untuk menjadi santri yang baik" (Wawancara salah satu warga masyarakat, 2020).

\section{Bidang Sosial Kemasyarakatan}

Selain sebagai lembaga pendidikan keagamaan, pondok pesantren juga berfungsi sebagai lembaga pengembangan sosial. Pesantren Berperan Sebagai lembaga sosial yang berkembang, dikembangkan secara bertahap sejalan dengan situasi negara, baik berada di pedesaan ataupun di perkotaan (Dewi, 2020).

Adapun kontribusi pondok pesantren Hidayatullah dalam bidang sosial, berfokus pada kegiatan yang bertujuan untuk meningkatkan Ukhuwah dengan masyarakat sekitar. Bentuk kegiatan tersebut antara lain adalah:

a. Mendirikan Panti Asuhan.

Panti asuhan didirikan bertujuan untuk membantu masyarakat sekitar yang kurang mampu, anak-anak yatim dan anak yatim piatu. Untuk mendapatkan pendidikan yang layak, dimana mereka dididik dan dibina agar kelak menjadi anak yang berguna bagi agama, bangsa dan negara.

b. Penyembelihan dan pembagian hewan kurban. 
Kegiatan ini berlangsung selama Idul Adha. Distribusi hewan kurban terus meningkat, baik dari sisi wilayah pembagian yang semakin meluas tidak hanya masyarakat sekitar tetapi juga masyarakat lainnya.

c. Mempelopori Kegiatan Keagamaan

Kegiatan ini memberi contoh dan memberi energi kepada masyarakat dengan menciptakan lingkungan masyarakat yang religius. Setiap kali ada hari besar umat Islam atau acara buka puasa bersama di masjid, Pesantren mewadahi kegiatan ini dan mendorong masyarakat untuk proaktif dan kreatif untuk mensukseskan acara tersebut. Kerjasama yang baik antara Pesantren dan masyarakat dapat menciptakan lingkungan keagamaan yang harmonis.

d. Koperasi Pondok Pesantren

Dalam aspek sosial, pondok pesantren Hidayatullah juga memberikan kontribusi terhadap dari segi ekonomi. Secara ekonomi, kontribusi pondok pesantren kepada masyarakat meliputi struktur kemitraan. Koperasi ini digunakan tidak hanya oleh santri tetapi juga oleh masyarakat sekitar (Ponpes Hidayatullah, 2020).

Dengan kata lain, begitu besar kontribusi pondok pesantren terhadap masyarakat sekitar. Oleh karena itu, kita harus menghargai dan menghormati keberadaan Pesantren dalam kehidupan masyarakat. karena keberadaan pesantren membawa pada kebaikan dan kemajuan dalam hal pendidikan Islam dan keagamaan.

\section{KESIMPULAN}

Pesantren adalah institusi sosial keagamaan yang merupakan sistem pendidikan Islam tertua di Indonesia, menjadi wahana pendidikan bagi umat Islam yang ingin mendalami ilmu-ilmu keagamaan Islam. Pondok Pesantren Hidayatullah berdiri di akhir tahun 1995 didirikan oleh Ust. Anwar Timumun, merintis dakwah di Bumi Tambun Bungai Kota Palangka Raya. Estafet kepemimpinan pondok pesantren Hidayatullah kini di pegang oleh Ust. Huzaifah. Konsep pendidikan Pesantren Hidayatullah berbasis Tauhid, dengan jenjang pendidikan terdiri dari PAUD, SD dan SMP. Pesantren Hidayatullah memiliki program seperti Diniyah Takmiliyah, serta beberapa program unggulan kurikulum Tarbiyah Ruhiyah, Tarbiyah Tsaqofiyah, Tarbiyah Jasadiyah, Tarbiyah Qiyadiyah dan Tarbiyah Ijtima'iyah. Adapun kontribusi pondok pesantren Hidayatullah bagi masyarakat diantaranya yaitu : (1) bidang pendidikan; kontribusi yang diberikan pondok pesantren berupa mendirikan sekolah formal dan non formal. (2) bidang keagamaan; mendirikan rumah tahfizh dan majelis taklim. (3) Bidang sosial kemasyarakatan; seperti mendirikan panti asuhan, pemotongan dan pembagian hewan kurban, acara keagamaan dan sebagainya.

\section{DAFTAR PUSTAKA}

Arikunto Suharsimi. 2010. Prosedur Penelitian : Suatu Pendekatan Praktis. Jakarta : Rineka Cipta.

Dewi, R. (2020). Kontribusi Pondok Pesantren Terhadap Perubahan Sosial Masyarakat Di Pulau Bangka (Studi Pondok Pesantren Al-Islam Desa Kemuja Kecamatan 
Mendo Barat Kabupaten Bangka). Tawshiyah: Jurnal Sosial Keagaman dan Pendidikan Islam, 15(2)

Engku, Iskandar \& Siti Zubaidah. 2014. Sejarah Pendidikan Islam. Bandung: PT Remaja Rosdakarya.

Kamus Besar Bahasa Indonesia, 2000. Jakarta : Balai Pustaka.

Mastuhu. 1994 Dinamika Sistem Pendidikan Pesantren Suatu Kajian Tentang Unsur dan Nilai Sistem Pendidikan Pesantren. Jakarta : INIS.

Muliawan, Jasa Unggah. 2005. Pendidikan Islam Integratif. Yogyakarta : Pustaka Pelajar.

Mun'im, Zainul A. Rafiq. 2009. Peran Pesantren dalam Education For All di Era Globalisasi. Jurnal Pendidikan Islam Vol. 1, No. 1.

NS Suwito, dkk. 2009. Model Pengembangan Ekonomi Pesantren. Purwokerto: STAIN Press.

Shiddiq, Ahmad, 2015. Tradisi Akademik Pesantren, Jurnal Tadris Vol.10. No. 2.

Shofiyyah, dkk. 2019. Model Pondok Pesantren di Era Milenial. Belajea; Jurnal Pendidikan Islam, Vol. 4, no. 1.

Proyek Pembinaan dan Bantuan kepada Pondok Pesantren. 1985. Standarisasi Pengajaran Agama di Pondok Pesantren, Dirjen Bimbaga Islam Depag RI.

Wawancara dengan Pimpinan Ponpes, Ust. Huzaifah, S.Sos. 15 Des 2020.

Wawancara dengan TU sekaligus Pengajar Pondok Ust. Arif Rahman, S.Pd. 15 Des 2020.

Wawancara salah satu Pengajar, Ustazah Usmayanti, S.Pd, 15 Des 2020.

Wawancara salah satu warga ibu Maisarah, 16 Des 2020.

Yunus, Mahmud. 2005. Sejarah Pendidikan Islam di Indonesia. Jakarta: Mutiara Sumber Widya.

Ziemek, Manfred. 1986. Pesantren dan Perubahan Sosial, Jakarta : P3M.

Zulhimma, 2013. Dinamika Perkembangan Pondok Pesantren di Indonesia. Jurnal Darul ‘llmi Vol. 1. No. 2 